\title{
SHALL THE AMERICAN DREAM SUFFER DEATH?
}

\author{
James Oury *
}

\section{INTRODUCTION}

"Shall Suffer Death" - Alan Jeffrey Bannister, Missouri capital punishment inmate number 24, has heard those words read to him on eight separate occasions throughout his nearly fifteen years of incarceration facing a sentence of death.

At the time of writing an introduction to this article I sit in a downtown bar in Washington D.C. whilst my client sits facing his eighth Warrant of Execution. Alan, or "AJ" as he has become known, has less than ten days before his execution, scheduled to take place by lethal injection within the confines of Potosi Correctional Facility at 12:01 am on Wednesday, 22nd. October, 1997. It seems to add to the perversity of Alan's circumstances that the Warrant of Execution referred to him as "ALLAN."

I appeared today in oral argument, opposed by representatives of the United States and Missouri Attorney General Departments, before the Inter-American Commission on Human Rights alleging violations of Mr.Bannister's rights as enshrined within the American Declaration of the Rights and Duties of Man and seeking precautionary relief in the form of:

(1) The United States to so act as to stay the execution of Mr. A.J. Bannister, pending a full review of his claims by the Commission;

(2) That the United States ensure that the sentence of death be not carried out in relation to Mr. A.J. Bannister for humanitarian reasons and to avoid irreparable damage to him; and

* Solcitor, Criminal Law, Partner, Oury Colhoun \& Co. - Representative of the U.S. Capital Litigation Project. 


\section{DENNING LAW JOURNAL}

(3) That these measures are to be without prejudice to the processing of the Complaint.

Those "rights" include his inherent right to life, (Article 1), his right to a fair trial, (Article XVIII), his right not to receive cruel, infamous or unusual punishment (Article XXVI) and his right to due process of law, (Article XXVI).

Ultimately, the decision as to whether Mr. Bannister lives or dies is highly likely to rest in the hands of the Governor of Missouri - the Honorable Mel Carnahan who is vested with a statutory power to exercise executive clemency (or mercy) by commuting Mr. Bannister's capital sentence to that of life without the possibility of parole.

Current circumstances have prevented me from adapting to "article form" the following text which is an Amicus Curiae Brief I prepared and, having obtained leave, filed in the United States Eighth Circuit Court of Appeals in October of last year. For this lack of adaption I can only apologise.

The brief was referred to by the three federal judges who adjudicated upon Mr. Bannister's constitutional claims in November but for procedural reasons only Mr. Bannister was denied relief and the merits of his constitutional claims were never adjudged. Dissenting, this absence of consideration was highlighted by Senior Circuit Judge Bright, who declared:

"Several of Bannister's allegations go to the heart of our perceptions of fundamental fairness in the criminal justice system: the right to be free from governmental interrogation after receiving appointed counsel, Michigan v. Jackson, 475 U.S. 625 (1986), the right to a competent attorney during trial, Strickland $\mathrm{v}$. Washington, 466 U.S. 214 (1988); Powell v. Alabama, 287 U.S. 45 (1932); and the right to a competent attorney during sentencing, Mempa v. Rhay, 389 U.S. 128 (1967); Townsend v. Burke, 334 U.S. 736 (1948). As discussed in the majority's opinion, procedural barriers prevent this court from addressing several of Bannister's claims. These roadblocks, I emphasize, are procedural and in no way reflect on the merits of Bannister's claims. If these issues remain unaddressed, Missouri may execute a man without offering him a fair trial or competent legal representation. Because this court cannot address those issues on their merits, we must rely on other authorities--either the United States Supreme Court or, if not, the Governor of Missouri--to review the record and address 


\section{SHALL THE AMERICAN DREAM SUFFER DEATH}

Bannister's contentions."

The Brief set out below is written accepting the legitimacy of the reservations expressed by the United States Senate having regard to the ratification of the International Covenant on Civil and Political Rights [I.C.C.P.R.] although material authority exists for the proposition that these reservations are ineffective having regard to the position on derogation expressed in Article 4 (2) of the I.C.C.P.R.

\section{INTERNATIONAL OBLIGATIONS}

On 8th. September, 1992, the United States of America, subject to reservations expressed by the United States Senate, ratified the I.C.C.P.R. Article 7 of the I.C.C.P.R. states that " $[\mathrm{n}] \mathrm{o}$ one shall be subjected to torture or to cruel, inhuman, or degrading treatment or punishment."

The reservation expressed by the United States in specific regard to Article 7 declared that:

"[t]he United States considers itself bound by Article 7 to the extent that "cruel inhuman or degrading treatment or punishment" means the cruel and unusual treatment or punishment prohibited by the Fifth, Eighth or Fourteenth Amendments to the Constitution of the United States"'

The United Nations Human Rights Committee commented that the negative obligations on a State imposed by Article 7 must be augmented by the positive requirement of Article 10(1) I.C.C.P.R, which states: "[a]ll persons deprived of their liberty shall be treated with humanity and with respect for the inherent dignity of the human person."'

On 20th. November, 1994, the United States, subject to a similar reservation expressed in regard to Article 7 I.C.C.P.R. by the United States Senate, ${ }^{3}$ ratified Article 16 of the Convention against Torture and other Cruel, Inhuman,

${ }^{1}$ Senate Treaty Doc. 95-2, see also White v. Johnson 79 F.3d 432 at 439 (5th.Cir.) (1996).

${ }^{2}$ Human Rights Committee, General Comment 7, Article 7 (Sixteenth Session, 1982), U.N. Doc. HRI\GEN/Rev. 1 at 7 (1994), Para.2.

${ }^{3}$ Senate Treaty Doc. $100-20$. 


\section{DENNING LAW JOURNAL}

or Degrading Treatment or Punishment ("the Convention"). The Convention prohibits the use of "torture or cruel, inhuman or degrading punishment or treatment."

Thus, the following legal analysis conducted in regard to the binding international obligations of the United States contained in Article 7 and 10(1) I.C.C.P.R. and Article 16 of the Convention interprets those binding obligations in regard to the use of the language of "cruel and unusual punishment," as contained in the Eighth Amendment of the Constitution of the United States.

\section{THE EIGHTH AMENDMENT}

Origin-Permissibility of delay by the Framers - Capital Punishment

"[I]n Gregg v. Georgia, 428 U.S. 153 (1976), this Court held that the Eighth Amendment does not prohibit capital punishment. Our decision rested in large part on the grounds that (1) the death penalty was considered permissible by the Framers." ${ }^{p 4}$

Section 10 Bill of Rights 1689

"'There is no doubt' that Section 10 of the English Bill of Rights of 1689 'is the antecedent' of the cruel and unusual punishment clause of our Eighth Amendment."

"As we have previously recognised, that section is undoubtedly the precursor of our own Eighth Amendment." ${ }^{.6}$

"There is now little room for doubt that the Eighth Amendment's ban on cruel and unusual punishment embraces, at a minimum, those modes or acts of punishment that had been considered cruel

${ }^{4}$ Lackey v. Texas 115 S.Ct. 1421 (1995) (Justice Stevens - Memorandum).

${ }^{5}$ Mckenzie v. Day, 57 F.3d. 1461 at 1487 n.18 (9th.Cir.1995) (William A. Norris dissenting) citing Harmelin v. Michigan, 111 S.Ct. 2680 at 2686 (1981) (Justice Scalia concurring).

${ }^{6}$ Lackey v. Texas, supra.n. 4 at 1422. 


\section{SHALL THE AMERICAN DREAM SUFFER DEATH}

and unusual at the time that the Bill of Rights was adopted."7

"There is a formidable case for suggesting that execution after inordinate delay would have infringed the prohibition against cruel and unusual punishment to be found in Section 10 of the Bill of Rights of $1689 \ldots . . .8$

In Pratt \& Morgan v. Attorney General of Jamaica, a period of five years was held to amount to "inordinate delay," as Lord Griffiths concluded:

"in any case in which execution is to take place more than five years after sentence there will be strong grounds for believing that the delay is such as to constitute inhuman or degrading punishment or other treatment."99

In Ricardo Farrington v. The Minister of Public Safety and Immigration and Others, as the Bahamas, as is the case for the United States, had no access to the remedial forum of the United Nations Human Rights Committee, as distinct from Jamaica, the five year period was reduced to three and a half years. The Privy Council concluded:

"It is the lapse of the whole period which is relevant to the question whether there has been inordinate delay. This is because the agony of mind is the same, whatever the cause of the delay.... the lapse of an overall period of time of $3 \frac{1}{2}$ years following sentence of death is indeed an inordinate time." 10

"Closely related to the basic question" as to whether the delay in carrying out

${ }^{7}$ Ford v. Wainwright, 106 S.Ct. 2595 at 2599 (1986).

${ }^{8}$ Riley v. Attorney General of Jamaica, [1983] 3 All E.R. 469 (P.C.) (Lord Scarman, dissenting, joined by Lord Brightman), majority opinion overruled by Pratt \& Morgan v. Attorney General of Jamaica, [1993] 4 All E.R. 769 (P.C.) (en banc). "American Courts have long been guided by the decisions of the Privy Council." Mckenzie v. Day supra.n. 5 \& see infra.n. 74 .

${ }^{9} \mathrm{Ibid}$ at $788 \mathrm{j}-789 \mathrm{a}$.

${ }^{10}$ [1996] 3 W.L.R. 1079 (P.C.) per Lord Goff of Chieveley. 


\section{DENNING LAW JOURNAL}

a death sentence violates the Eighth Amendment "is a question concerning the portion of the...delay that should be considered in the analysis...[i]t may be appropriate to distinguish, for example, among delays resulting from (a) a petitioner's abuse of the judicial system by escape or repetitive, frivolous filings; (b) a petitioner's legitimate exercise of his right to review; and (c) negligence or deliberate action by the State."

"The fact that the delay may be due to the defendant's insistence on exercising his appellate rights does not mitigate the severity of the impact on the condemned individual, and the right to pursue due process of law must not be set off against the right to be free from inhuman treatment."12

The "delay resulting from meritorious challenges" initiated by "capital prisoners.....certainly cannot be held against them." 13 "[T] he relevant inquiry is not who is to blame for the delay, but whether the petitioner's claims were "a legitimate exercise of [his] right to review."14

In this case " $\mathrm{t}] \mathrm{he}$ State does not contend that the delay in 'the Appellant's case' is even remotely attributable to petitioner's 'repetitive, frivolous,' or otherwise illegitimate filings, [nor would such a contention be supported by the record]." The Appellant has been imprisoned on death row for in excess of thirteen and a half years, such a period reflecting the exercise of his legitimate right to review. Further, the delay arising from such exercise of the Appellant's legitimate right to review should not be disregarded: ${ }^{16}$

${ }^{11}$ Lackey v. Texas, supra.n.4 at 1422, citing Pratt \& Morgan v. Attorney General of Jamaica, supra.n.8 at 786.

${ }^{12}$ District Attomey for the Suffolk District v. Watson 411 N.E. 2d. 1274 at 1283, n.7 (Sup. Ct. Mass.) (1980).

${ }^{13}$ Arizona v. Richmond 886 P.2d 1329 at 1332 (Sup. Ct. Ariz.) (1994).

${ }^{14}$ Mckenzie v. Day supra.n. 5 at 1485.

15 Ibid.

16 "It seems to me highly artificial and unrealistic to discount the mental agony and torment experienced on death row on the basis that by not making the maximum use of the judicial process available the condemned prisoner would have shortened and not lengthened his suffering. The situation could be otherwise if he had resorted to a series of untenable and 


\section{SHALL THE AMERICAN DREAM SUFFER DEATH}

"It was part of the human condition that a condemned man would take every opportunity to save his life through use of appellate procedure. If it enabled the prisoner to prolong the appellate hearings over a period of years, the fault was to be attributed to the appellate system that permitted such delay and not to the prisoner who took advantage of it."'17

To proceed with the execution of Mr. Bannister after what amounts to an "inordinate delay," after in excess of thirteen and a half years, would be contrary to Section 10 of the English Bill of Rights 1689. ${ }^{18}$ A fortiori, to proceed with Mr. Bannister's execution would amount to a "mode" or "act" of "punishment," which is, at a minimum, (emphasis added), protected by the Eighth Amendment. ${ }^{19}$

\section{Framers of the Constitution}

"A delay such as in this case, if it ever occurred, certainly would have been rare in 1789, and thus the practice of the Framers would not justify a denial of the petitioner's claim."20

"Over a century ago this Court recognised that "when a prisoner sentenced by a court to death is confined in the penitentiary

vexatious proceedings which, in consequence, had the effect of delaying the ends of justice." in Catholic Commission for Justice and Peace in Zimbabwe v. Attorney General (1993) 14 H.R.L.J. 323 (Cubbay C.J.) (24th.June, 1993), Soering v. U.K. 11 E.H.R.R. 439 (1989), "We think that the case of the delay is immaterial when the sentence is death. Be the cause of the delay, the time necessary for the appeal and consideration of reprieve or some other cause for which the accused himself may be responsible, it would not alter the dehumanising character of the delay." See also, Vatheeswaran v. State of Tamil Nadu (1983) 2 S.C.R. 348 at 353 per Chinnappa Reddy J. (1983), approved in Sher Singh v. State of Punjab (1983) 2 S.C.R. 582 and Smt.Treveniben v. State of Gujarat (1989) 1 S.C.J. 383 (Supreme Court of India).

${ }^{17}$ Pratt \& Morgan v. Attorney General of Jamaica, supra.n. 8 at 786.

${ }^{18}$ Riley v. Attorney General of Jamaica, supra.n.8.

${ }^{19}$ Ford v. Wainwright supra.n.7.

${ }^{20}$ Lackey v. Texas, supra.n.4 at 1421. 


\section{DENNING LAW JOURNAL}

awaiting the execution of the sentence one of the most horrible feelings to which he can be subjected during that time is the uncertainty during the whole of it." 21

"If the Court accurately described the effect of uncertainty in Medley, which involved a period of four weeks....that description should apply with even greater force in the case of delays that last for many years." 22

"There are powerful reasons for concluding capital cases as promptly as possible....[f]rom the standpoint of the defendant, the delay can become so excessive as to constitute cruel and unusual punishment prohibited by the Eighth Amendment." 23

In Lackey v. Texas, the petitioner had spent approximately seventeen years facing a sentence of death. Justice Stevens noted that the first ground cited in Gregg v. Georgia, ${ }^{24}$ did not retain "any force." 25

To proceed with Mr. Bannister's execution after a period of in excess of thirteen and a half years facing a sentence of death would have been interpreted as "cruel and unusual punishment," in contravention of the Eighth Amendment.

\section{SOCIAL PURPOSES - DEATH PENALTY - RETRIBUTION AND DETERRENCE}

In addition to the ground cited above, in holding that capital punishment was not prohibited by the Eighth Amendment in Gregg v. Georgia, ${ }^{26}$ the decision

${ }^{21}$ In re Medley 134 U.S. 160 at 172 (1890).

${ }^{22}$ Supra.n.4 at 1421. See also the extensive list of authorities cited by Justice Stevens at 1422 .

${ }^{23}$ Gomez \& Calderon v. Fierro \& Ruiz 117 S.Ct.285 (1996) (Justice Stevens and Justice Breyer dissenting).

${ }^{24} 428$ U.S. 153 (1976).

${ }^{25}$ Supra.n. 4 at 1421.

${ }^{26}$ Supra.n.24. 


\section{SHALL THE AMERICAN DREAM SUFFER DEATH}

also rested on the grounds that "the death penalty might serve two principal social purposes: retribution and deterrence." 27

\section{Retribution}

"The prospect of pending execution exacts a frightful toll during the inevitable long wait between the imposition of sentence and the actual infliction of death." ${ }^{28}$

Death sentences, "will be carried out only after agonizing months and years of uncertainty" " 29 "T $]$ he interval between sentencing and execution.....the imprisonment during that period is nevertheless a significant form of punishment. $" 30$

"There can be little doubt that delay in the enforcement of capital punishment frustrates the purpose of retribution." 31

"It becomes clear that... presents a strong case. The years... has spent on death row appear to be unprecedented. This delay, coupled with the allegedly harsh and punitive confinement conditions on death row arguably satisfies the State's interest in exacting retribution." 32

Mr Bannister has faced a sentence of death for in excess of thirteen and a half years. "His thoughts about death must necessarily be focused more precisely than other people's. He must wait for a specific death, not merely expect death

${ }^{27}$ Lackey v. Texas supra.n. 4 at 1421.

${ }^{28}$ Furman v. Georgia, 408 U.S. 238 at 288-289 (1972) (Justice Brennan concurring).

${ }^{29}$ District Attorney for Suffolk District v. Watson, supra.n. 12 at 1287.

${ }^{30}$ Coleman v. Balcom 451 U.S. 949 (1981) (Justice Stevens) (majority opinion).

${ }^{31}$ Ibid. (Justice Rehnquist dissenting).

${ }^{32}$ Mckenzie v. Day, supra.n.5 at 1486. 


\section{DENNING LAW JOURNAL}

in the abstract." "33 "[W] hat man experiences at such times is beyond all morality....[h]aving to face an inevitable death, any man, whatever his convictions, is torn asunder from head to toe. The feeling of powerlessness and solitude of the condemned man, bound up and against the public coalition that demands his death, is in itself an unimaginable punishment." 34 "[I]n Death Row, organised and controlled in grim caricature of a laboratory, the condemned prisoner's personality is subjected to incredible stress for prolonged periods of time." ${ }^{35}$ As Mr. Bannister remarks:
"How will I say goodbye to my wife, my mother, brothers and sisters, nieces and nephews? How will I act at the moment in time when they come over there, I would already have been in the holding cell in the hospital?

How am I going to react? Are they going to lift me up onto the gurney or are they going to have the nerve to ask me to hop up there for them?"36

Ultimately Mr. Bannister has, for in excess of thirteen and a half years, faced the prospect of his own death, the "king of all terrors," ${ }^{37}$ knowing "that the state is very serious about carrying out executions." " ${ }^{38}$ Indeed, Mr. Bannister's ongoing agonizing experience can only have been augmented by his direct knowledge whilst housed on death row of the executions of 22 fellow inmates,

${ }^{33}$ See J.P. Sartre, Being and Nothingness (ed.Barnes) (1969) at 685-687.

${ }^{34}$ A.Camus, Reflections on the Guillotine, in Resistance, Rebellion, and Death, (1960) at $155-156$.

${ }^{35}$ West, "Psychiatric Reflections on the Death Penalty," in Voices against Death (ed.P.Mackey) (1976) at 290-291. See also Robert Johnson \& John L. Carroll, "Litigating Death Row Conditions: The Case for Reform," in Prisoners \& the Law (ed.I. Robbins) (1988) [quoting Robert Johnson, "Under Sentence of Death: The Psychology of Death Row Confinement," $5 L$. \& Psychol. Rev. 141 (1979)].

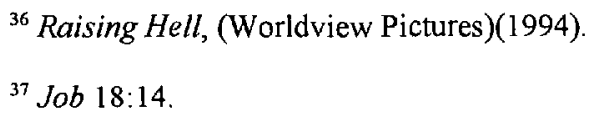

${ }^{38}$ Stephen Trombley, The Execution Protocol, (Crown Publishers Inc., New York, 1992) Appellant's comment at 190 . 


\section{SHALL THE AMERICAN DREAM SUFFER DEATH}

from 6th. January, 1989 to date, including the first execution by lethal injection of Mr. Bannister's friend and next door neighbour, George C. Mercer, on 6th. January, 1989.

21st. February, 1985: An execution date having been scheduled for 21 st. February, 1985, Mr. Bannister received a stay of execution on 15th. February, 1985. Mr. Bannister in describing events in 1985 states: "I think that's the worst part of the execution, the years and years prior to it, leading up." ${ }^{39}$

30th. July, 1987: An execution date having been scheduled for 30 th. July, 1987, Mr. Bannister received a stay of execution on 23rd. July, 1987.

3rd. November, 1988: An execution date having been scheduled for 3rd. November, 1988, Mr. Bannister received a stay of execution on 28th. October, 1988.

7th. December, 1994: A further execution date having been scheduled for 7 th. December, 1994, Mr. Bannister received a stay of execution at 9:49 pm by the United States Supreme Court in a vote of six to three. Mr Bannister was made aware of this final hour stay at 10:15 pm. ${ }^{40}$

Mr. Bannister provides a detailed personal account of events and emotions preceding this execution date and states: "My trip to the edge was set in motion on October 31, 1994," 41 "Assistant Superintendent Roper and Major Harris...hand delivered the execution warrant to me." ${ }^{42}$ On 28th. November, $1994 \mathrm{Mr}$. Bannister was called to the office of Warden Delo and, "he basically explained the procedure to me, including the fact that one of the shots on the eve of the execution was not optional, he told me it was a antihistamine and that was...to relax the lungs so that the second drug would not...there would be no adverse reaction. He also told me that they were treating this as a serious

${ }^{39} \mathrm{Ibid}$. at 235 .

${ }^{40}$ A.J. Bannister, .....Shall Suffer Death, (Audenreed Press, Maine, 1996) at 69.

${ }^{41}$ Ibid. at 69 .

${ }^{42}$ Supra.n. 36. 


\section{DENNING LAW JOURNAL}

exercise, almost jokingly asked me if I had made any funeral arrangements and asked me to get the telephone number of the mortuary where my mother lives, he explained the local mortuary would do the embalming." 43

On the evening of 2 nd. December, $1994 \mathrm{Mr}$. Bannister was taken to the holding cell within the hospital complex to await his execution.

In the early morning of 6th. December, $1994 \mathrm{Mr}$. Bannister's mother, Alice, visited her son for the last time:

"Her eyes were bloodshot, her voice was cracking and I just told her that she had been a great mother... the guard did allow me to lean over and we kissed through the chuckhole..... when they took her outside the room I had to look at her until the door closed, I listened to her footsteps going down the hallway for as long as I could...." "44

On 6th. December, 1994 Mr. Bannister's wife, Lindsay, visited her husband for the last time:
"She held up fairly well but I could see her eyes were red....bloodshot and she hadn't slept in days and there were a number of times I had to stick my fingers through the bar and she clinched my fingers on the outside and she would tell me that she loved me. ${ }^{.45}$

On the eve of the execution, inter alia, Mr. Bannister was provided with his last meal $(4.30 \mathrm{pm})$, he was read the "Notice of Intent," which concludes, "[i]t is the Department of Corrections intent to put you to death on December 7, 1994 at 12:01 pm, or at any time on December 7th."(7.00 pm), Mr. Bannister was introduced to the male nurse who would be responsible for fitting the I.V. (7.00 $\mathrm{pm})$, administered the antihistamine injection $(7: 15 \mathrm{pm})$, attended by a nurse to check his temperature, blood pressure and available veins in the left elbow joint area $(8.30 \mathrm{pm})$ and advised by Warden Delo that "the body" would be moved to Gunn \& Sons funeral home and held there for 24 hours at which time if nobody
${ }^{43} \mathrm{Ibid}$.
${ }^{44}$ Ibid.
${ }^{45}$ Ibid. 


\section{SHALL THE AMERICAN DREAM SUFFER DEATH}

had claimed the body, Mr. Bannister would be given a pauper's burial $(9.00 \mathrm{pm}) .^{46}$

As Mr. Bannister concludes: '[i]t's something I wouldn't wish upon anyone. I felt they walked me thorough hell and tried to push me along as much as they could.".47

The numerous instances of Mr. Bannister's suffering have deeply affected many other individuals involved in his day to day life.

"The waiting is very hard on his family but I know it is much harder on him."(Alice Bannister) ${ }^{48}$

"What am I going to say to him? How can I tell him everything I have always told him before but for the last time?'(Lindsay

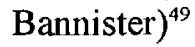

"I think she is going to take it real real hard. She has tried everything under her power to help him and it don't seem to have done any good. I think she will come close to a nervous breakdown. She thinks she will have failed all along the line."(Bob Bannister, Mr. Bannister's father) ${ }^{50}$

"For his nieces and nephews they're not going to understand why you know..... of why somebody is being killed for apparently no reason to them."(Sheila Bannister, Mr. Bannister's sister-in-law) ${ }^{51}$

In addition to this catalogue of suffering Mr. Bannister has endured, whilst housed in the basement of Missouri State Penitentiary, for in excess of six years, cruel and inhuman prison living conditions. A complaint was filed on

\footnotetext{
${ }^{46}$ Supra.n. 40 at 66-69.

${ }^{47}$ Supra.n.36.

${ }^{48}$ Ibid.

${ }^{49}$ Ibid.

${ }^{50}$ Ibid.

${ }^{51}$ Ibid.
} 


\section{DENNING LAW JOURNAL}

19th. August, 1985 in the United States District Court Western District of Missouri seeking declaratory and injunctive relief from the intolerable and unlawful conditions prevailing for inmates facing a sentence of death, housed in the basement of Missouri State Penitentiary [M.S.P.] ${ }^{52}$ The Appellant was one of the original five Plaintiffs in this action. On 15th. January, 1986 the Court (the Honorable Scott O.Wright) granted the Plaintiffs' motion for class action status and the certified class included all existing and future inmates confined under sentence of death at the M.S.P.

The complaint alleged that the Plaintiff class was "confined under conditions which [were] unconscionably oppressive and degrading and which violate[d] plaintiff's basic constitutional rights." It detailed 52 separate facts specific to death row at M.S.P., being inter alia:

Cell confinement for an average of $231 / 2$ hours per day; $2 \frac{1}{4}$ hours of outdoor recreation per week; 3 , often cancelled, showers per week, lasting 10-15 minutes each; no day rooms or common areas; available cell area of 20 square feet; extremely limited natural light due to paint and frosting on windows; overflowing of sinks and toilets into cells; unsanitary drinking water; inadequate ventilation; noxious air; poor bulb lighting in cells; extremely high noise levels; roach and fly infected cells; mattresses were never cleaned and blankets were cleaned once a year; squalid seclusion cells; cold and unsanitary food; denial of food for $17 \frac{1}{2}$ hours per day; no group religious services; no access to law library and limited access in cells to legal materials; inadequate medical, dental, psychiatric and counselling care; limited access to telephone; tampering with legal and other mail and inadequate fire safety. ${ }^{53}$

The Plaintiffs alleged in the complaint that they, as inmates confined under a sentence of death, had suffered and were suffering violations of their rights under the First, Sixth, Eighth and Fourteenth Amendments to the Constitution of the United States. As the Complaint details: "[c]onfinement of plaintiffs for periods of many years under the conditions alleged herein is dehumanising and damaging to plaintiffs' physical and psychological health and safety."

${ }^{52}$ Case No. 85-4422-CV-C-5.

${ }^{53}$ Supra.n.38 at $121 \&$ n. 40 at 46. 


\section{SHALL THE AMERICAN DREAM SUFFER DEATH}

The complaint resulted in a settlement embodied in a Consent Decree ("the Decree") in 1986. The Decree, although not representing findings of fact or conclusions of law, indirectly affirmed the legitimacy of the Plaintiff's allegations in detailing remedial steps to be taken "with the utmost speed," in regard to, inter alia:

medical services; mental health care; recreation; telephone access; facilities for indoor recreation; plumbing; renovation works; food service ramp; fire safety; visiting; education; lighting; sanitation; window screening; feeding; legal mail and materials; classification and additional staffing.

The Decree was "a plan for ensuring that the capital punishment unit complies with constitutional requirements." ${ }^{34}$

Although various steps were taken by the prison authorities to effect the contents of the Decree a dispute arose between the parties over certain aspects of the implementation of the Decree. This dispute ultimately led to the appointment of a Special Probation Office on 15th. October, 1987.

It is submitted that it was not until the moving of Mr. Bannister to Potosi Correctional Facility in early May, 1989 that such constitutional requirements were fully met and thus the Appellant endured inhuman and degrading prison living conditions for in excess of six years whilst facing a sentence of death.

There can be no doubt that Mr. Bannister's lengthy incarceration facing a sentence of death amounts to "a significant form of punishment," 55 which "has exacted a frightful toll," " incredible stress, pain and suffering already endured by Mr. Bannister, his wife, family and friends as a result of a lengthy period facing a sentence of death is heightened to unimaginable levels with the inclusion of the events pertaining to the scheduled execution dates, the knowledge of 22 previously executed prison inmates and the inhuman prison living conditions Mr. Bannister endured for a significant portion of his incarceration on death row.

In Lackey v. Texas, the petitioner sought to argue that his enduring of a seventeen year period facing a sentence of death, per se, violated the Eighth

${ }^{54}$ McDonald v. Armontrout, 908 F. 2 d 388 (8th.Cir.1990).

${ }^{55}$ Coleman v. Balcom supra.n. 30.

${ }^{56}$ Furman v. Georgia, supra.n.28. 


\section{DENNING LAW JOURNAL}

Amendment's prohibition against cruel and unusual punishment, "after such an extended period of time, the acceptable state interest in retribution has arguably been satisfied by the severe punishment already inflicted." ${ }^{57}$ The "extraordinary" and "unusual" facts of the final days and final hour Stays of Execution in 1985, 1987, 1988 and 1994 and the inhuman prison living conditions distinguish this case from the facts in Lackey v. Texas, and White $\mathrm{v}$. Johnson. ${ }^{58}$ The combination and cumulative effect of the sufferable events $\mathrm{Mr}$. Bannister has endured dissolves the "arguable" status referred to in Lackey v. Texas, and provides with no doubt that the acceptable state interest in retribution has been fully satisfied.

As Mr. Bannister notes:

"Taken to the edge doesn't end there, it is an ongoing experience....I wondered, then as I do now, if by some cruel twist of fate, myself, my friends and my family will have to be put through this again?"'s9

A fortiori, to proceed with Mr. Bannister's execution would serve no purpose in satisfying the state's interest in retribution.

\section{Deterrence}

"[T]he deterrent value of incarceration during that period of uncertainty may well be comparable to the consequences of the ultimate step itself."

"The deterrent value of any punishment is, of course, related to the promptness with which it is inflicted." ${ }^{\prime 61}$

"Finally the additional deterrent effect from an actual execution

${ }^{57}$ Supra.n. 4 at 1421.

${ }^{58}$ Supra.n.1 at 439.

${ }^{59}$ Supra.n.40 at 70 .

${ }^{60}$ Coleman v. Balcom, supra.n. 30 at 2033 (Justice Rehnquist dissenting).

${ }^{61}$ Ibid (Justice Stevens concurring). 


\section{SHALL THE AMERICAN DREAM SUFFER DEATH}

now, on the one hand, as compared to [17] years on death row followed by the prisoner's continued incarceration for life, on the other, seems minimal." 62

"Delay in the execution of judgment imposing the death penalty frustrates the public interest in deterrence and eviscerates the only rational justification for that type of punishment. ${ }^{963}$

Mr. Bannister, through his extensive participation in correspondence with individuals around the world, in books and films, ${ }^{64}$ and as a subject of local and national television and newspaper news, has sought to educate the public of his bitter repentance and remorse for his actions and of his continued parameterless suffering whilst on death row. It is nothing less than a testament to his character that even after the final hour stay on 6th. December, 1994 he went on to write a book, published in 1996, ${ }^{65}$ which continued to express remorse for his acts - "I was gripped by the grim realisation I'd taken a life. There is no sicker feeling than to know one's responsible for the loss of another human being's life.'266

It is clear from the evidence that Mr. Bannister, after in excess of thirteen and a half years, "is no longer the same person." 67 The potential for Mr. Bannister to reinsert himself back into society is also corroborated by the many individuals who have been part of Mr. Bannister's life, from his family members, law enforcement officers, correctional officers, lawyers, and many residents within the international community. To execute Mr. Bannister having repented and remorsed his acts openly despite having endured such a publicized extreme catalogue of suffering for in excess of thirteen and a half

${ }^{62}$ Lackey v. Texas, supra.n.4 at 1421.

${ }^{63}$ Gomez \& Calderon v. Fierro \& Ruiz supra.n.23. See also supra.n.1; "Years of delay between sentencing and execution.....undermines the deterrent effect of capital punishment and reduces public confidence in our criminal justice system" Justice Lewis Powell, "Commentary: Capital Punishment" 102 Harv.L.Rev. 1035 at 1035 (1989).

${ }^{64}$ Supra.n.36, n.38 \& n.40.

${ }^{65}$ Supra.n.40.

${ }^{66} \mathrm{Ibid}$. at 35 .

${ }^{67}$ Arizona v. Richmond, supra.n.13 at 1336 


\section{DENNING LAW JOURNAL}

years would offer no value to society in deterrence terms and would amount to punishing another man.

Mr. Bannister's execution under circumstances where neither the state's interest in retribution nor deterrence would be served would amount to a "pointless and needless extinction of life with only marginal contributions to any discernable social or public purposes. A penalty with such negligible returns to the State would be patently excessive and cruel and unusual punishment violative of the Eighth Amendment. $"{ }^{.68}$

\section{EVOLVING STANDARDS OF DECENCY}

\section{United States Authority}

"The clause seems to express a great deal of humanity, on which account I have no objection to it." Remark of Mr Livermore during the discussion of the Eighth Amendment at the First Congress. ${ }^{69}$

"[T]he basic concept underlying the [clause] stands to assure that this power be exercised within the limits of civilised standards."

The Eighth Amendment recognises the "evolving standards of decency that mark the progress of a maturing society," 71 and protects "fundamental human dignity." "The purpose of the cruel and unusual punishment prohibition is to guarantee a measure of human dignity even to the wrongdoers in our society."

${ }^{68}$ Furman v. Georgia, supra.n.28 at 312 (opinion concurring in judgment). See also Judge Alex Kozinski, "Death: The Ultimate Run-On Sentence" 46 Case W.Res.L.Rev. 1 at 1-2 (Fall 1995); Gomez \& Calderon v. Fierro \& Ruiz, supra.n.23.

${ }^{69} 1$ Annals of Cong. 754 (1789), Groseclose v. Dutton, 609 F. Supp. 1439 (1985) (Dist. Ct. M.D. Tennessee).

${ }^{70}$ Trop v. Dulles, 356 U.S. 86 at 100-101 (1958) (plurality opinion), cited in Gregg v. Georgia, supra.n.24 at 269-270 (Justice Brennan).

${ }^{71}$ Trop v. Dulles, ibid. at 101.

${ }^{72}$ Coker v. Georgia, 433 U.S. 584 at 597 (1977) (plurality opinion).

${ }^{73}$ District Attorney for Suffolk District v. Watson, supra.n. 12 at 295. 


\title{
SHALL THE AMERICAN DREAM SUFFER DEATH
}

International Authority ${ }^{74}$

\begin{abstract}
"There is an instinctive revulsion against the prospect of hanging a man after he has been held under sentence of death for many years. What gives rise to this instinctive revulsion? The answer can only be our humanity."75
\end{abstract}

In Soering v. United Kingdom, the United States had applied to the United Kingdom to extradite the applicant to stand trial in the State of Virginia on a charge of capital murder. ${ }^{76}$ The applicant alleged that extradition to face possible death row delays of six to eight years was contrary to Article 3 of the European Convention for the Protection of Human Rights and Fundamental Freedoms which provides that no one should be subjected to torture or to inhuman or degrading treatment or punishment. The European Court of Human Rights held that the decision to extradite the applicant to the United States would, if implemented, give rise to a breach of Article 3 of the Convention. The exposure to the death row phenomenon went beyond the threshold set by Article 3.

To proceed with the execution of Mr. Bannister would be nothing short of an absolute disregard for the retention of the measure of human dignity which $\mathrm{Mr}$. Bannister, in the light of the extreme catalogue of suffering he has already endured, constitutionally deserves and which our humanity demands.

\section{INTERNATIONAL AUTHORITIES}

\section{Jamaica}

In Pratt \& Morgan v. Attorney General for Jamaica, the Privy Council unanimously held that to execute two inmates who had been on death row for fourteen years and who had been read execution warrants on three occasions would constitute "torture or....inhuman or degrading punishment" in

${ }^{74}$ In refusing to hear these claims, the Court turns a deaf ear to an argument that courts in other countries have found persuasive. See, e.g., State v. Makwanyane \& Mchunu, Case No. CCT/3/94 (So.Afr. Const.Ct. 6th.June, 1995); Pratt \& Morgan v. Attorney General of Jamaica supra.n.8; Gomez \& Calderon v. Fierro \& Ruiz, supra.n.23.

${ }^{75}$ Pratt \& Morgan v. Attorney General of Jamaica, ibid. at $783 \mathrm{f}$.

${ }^{76}$ Supra.n. 16. 


\section{DENNING LAW JOURNAL}

violation of section 17(1) of the Jamaican Constitution, a document rooted in the English common law." "77 As Lord Griffiths declared:

"The statement of these bare facts is sufficient to bring home to the mind of any person of normal sensitivity and compassion the agony of mind that these men must have suffered as they have alternated between hope and despair in the 14 years that they have been in prison facing the gallows." ${ }^{.78}$

\section{Trinidad and Tobago}

Pratt \& Morgan v. Attorney General of Jamaica, ${ }^{79}$ received unanimous approval in Guerra v. Baptiste and others, where the execution of the appellant after a delay of four years and ten months, during which time the appellant had been on death row, was held to be a "cruel and unusual....punishment" contrary to section 5(2)(b) of the Constitution of Trinidad and Tobago and their Lordships "announced immediately that the appeal would be allowed and the appellant's sentence of death commuted to a sentence of life imprisonment." It is of importance that in Guerra the petitioner was subject only to a single warrant of execution.

\section{Zimbabwe}

In Catholic Commission for Justice \& Peace in Zimbabwe v. AttomeyGeneral the Supreme Court of Zimbabwe held that prolonged death row incarceration constituted "inhuman or degrading punishment" in violation of its Constitution and thus forbade the execution of four prisoners confined under sentence of death for between $41 / 3$ to 6 years. ${ }^{81}$

\section{India}

${ }^{77}$ Mckenzie v. Day, supra.n.5 at 1487.

${ }^{78}$ Pratt \& Morgan v. Attorney General of Jamaica, supra.n. 8 at $772 \mathrm{~h}$.

${ }^{79}$ Ibid.

${ }^{80}[1985] 4$ All E.R. 583 at 587 (P.C.).

${ }^{81}$ Supra.n. 16. See also Conwayo v. Minister of Justice (1992) (2) S.A. 56 at 64 B (Zimb. S. Ct.) where the Zimbabwe Supreme Court held, inter alia, that a lack of exercise constituted "inhuman treatment." 
In Vatheeswaran v. State of Tamil Nadu, the court held that delay exceeding two years in the execution of a sentence of death should be sufficient to entitled a person under sentence of death to demand the quashing of his sentence on the ground that it offended against Article 21 of the Indian Constitution which provides, "[n]o person shall be deprived of his life or personal liberty except according to procedure established by law. ${ }^{1782}$

\title{
Belize
}

In Logan v. $R$, the appellant, who had been facing a sentence of death for approximately three years, was granted a conservatory order prohibiting his execution by the Privy Council three days before his only scheduled execution date pending the lodging of a petition for special leave to appeal to the Privy Council. ${ }^{83}$ Lord Steyn concluded:

\begin{abstract}
"Ultimately, their Lordships have concluded that, in the light of the fact that the appellant has been under sentence of death for some three years, and very close to execution before the conservatory order was granted, such an order" [being to remit the case to the Court of Appeal in Belize to consider whether there should be a retrial] "would be unjust. In the result their Lordships will humbly advise Her Majesty that the conviction of murder and sentence of death should be quashed." ${ }^{84}$
\end{abstract}

\section{The Bahamas}

In Ricardo Farrington v. The Minister of Public Safety and Immigration and Others, ${ }^{85}$ and Dwight Lamott Henfield $\mathrm{v}$. The Attorney General of the Commonwealth of The Bahamas, ${ }^{86}$ each appellant had been read a single execution warrant and had spent three years and four months and six years

${ }^{82}$ Supra.n.16. See also Batra v. Delhi Administration (1979) 1 S.C.R. 392 at 457D \& 488 F-H, where the Supreme Court of India held that all normal prison facilities of movement, association and reading should be available for condemned prisoners.

${ }^{83}$ [1996] 4 All E.R.190 (P.C.).

${ }^{84}$ Ibid. at 204.

${ }^{85}$ Supra.n. 10.

${ }^{86}$ [1996] 3 W.L.R. 1079 (P.C.) (Lord Goff of Chieveley). 


\section{DENNING LAW JOURNAL}

and six months facing a sentence of death respectively. In respect of both cases the Privy Council concluded, "that a period of $3 \frac{1}{2}$ years in prison awaiting execution, with all the agony of mind that entails, would in all the circumstances be so prolonged a time as to render execution cruel or inhuman punishment."

To execute Mr. Bannister who has endured not only many years facing a sentence of death but has also endured inhuman prison living conditions for over six years, the issuing of seven Warrants of Execution on a systematic basis throughout his period of incarceration, the direct knowledge of 22 fellow inmate executions, the independent scheduled execution dates which subjected the Appellant in 1985, 1987, and 1988 to final days stays of execution and ultimately, in 1994, to a final hour stay of execution which augmented the already heightened level of physical and emotional suffering Mr. Bannister had endured as the "Missouri Execution Protocol" was progressed to its penultimate conclusion would be inherently contrary to the decisions of the Privy Council and many other international jurisdictions in factual comparison terms as well as being contrary to prevailing international standards of human dignity and decency.

Indeed, Pratt \& Morgan appears to be the only international authority which only factually proximates the extreme severity of such a combination of sufferable, inhuman and cruel events that Mr. Bannister has endured whilst facing his sentence of death for in excess of thirteen and a half years.

International authority demands that the exceptional erosion of Mr. Bannister's dignity and humanity to date be remedied by an immediate commutation of his death sentence.

To proceed with Mr. Bannister's execution would amount to cruel and unusual punishment as provided in the Eighth Amendment of the Constitution of the United States. A fortiori, such a constitutional violation would amount to clear violations of Article 7 and Article 10(1) I.C.C.P.R. and Article 16 of the Convention.

In these compelling and insufferable circumstances, both United States and international authority, the need to protect Mr Bannister's dignity and our humanity clearly demand that his sentence of death be immediately commuted, "bring[ing] to an end this unfortunate saga," ${ }^{87}$ and that in so doing this Honorable Court would be treating Mr. Bannister as a "unique individual human being" and not as a "member of a faceless, undifferentiated mass to be

${ }^{87}$ Arizona v. Richmond,supra.n.13 at 1333. 


\section{SHALL THE AMERICAN DREAM SUFFER DEATH}

subjected to the blind infliction of the death penalty."

\section{CONCLUSION}

As I conclude this article I am reminded of Mr Bannister's often spoken words to me during the course of our many conversations that were penetrated by an automated voice announcing - "This call originated from a Correctional Facility" - "Keep the faith - Keep the faith...."

Facing his eighth execution warrant, Mr. Bannister had been read the Warrant within yards of the execution chamber itself, introduced to the execution team, and advised of the removal of his right to contact visits with his family and legal team.

Mr. Bannister's catalogue of suffering continued ...

Following over 10,000 letters of request sent to the Governor urging mercy, domestic and international television and newspaper coverage and oral representations made to the Governor and his legal counsels, Alan was denied clemency at $4.00 \mathrm{pm}$ on Wednesday $22 \mathrm{nd}$. October, 1997 and was executed by lethal injection at $12.01 \mathrm{am}$. Alan suffered many deaths whilst facing his capital sentence - I hope he is finally at peace, free from physical and psychological brutality. In this instance of barbarity there is no doubt that, for me, the American Dream suffered death.

${ }^{88}$ Woodson v. North Carolina, 96 S.Ct. 2978 at 2980 (1976) (Justices Stewart, Powell and Stevens). 